\section{Abbott and Hybritech settle dispute \\ Washington}

THE long-running patent dispute between Abbott Laboratories and the Hybritech subsidiary of Eli Lilly over the 'sandwich' immunoassay technique has come to an end. The two companies have entered into a confidential settlement involving "licenses and cross-licenses" of each other's sandwich-assay patents and related patent applications. The sandwich-assay technology uses two monoclonal antibodies to capture small quantities of the antigen to be detected, making an antibody-antigenantibody 'sandwich'. The worldwide market for all immunodiagnostics is estimated to be $\$ 5,000$ million.

Abbott was banned from selling kits using the sandwich-assay technique when Hybritech brought suit against the company two years ago. The same year, Hybritech used its patent to drive Monoclonal Antibodies, Inc. out of the market, and nearly out of business, by forcing the company's marketing partner, Ortho Diagnostics, to suspend sales of several kits using the assay.

But the settlement of the HybritechAbbott suit leaves unanswered which company deserves the credit for first using monoclonal antibodies in immunoassays, after they had been invented by Kohler and Milstein in 1975. Some argue that using monoclonals in immunoassays should not be patentable in itself, because monoclonals offered obvious advantages over the polyclonal antibodies that were already in wide use (see Nature 340, 256; 1989).

The US patent office is attempting to settle the question. An investigation, termed an 'interference' proceeding, is under way to determine whether Hybritech, Hoffman LaRoche or La Jolla Cancer Research Foundation of California thought of the idea first. The three companies claim conception dates within months of one another.

Carol Ezzell

\section{New battle over TPA \\ washington}

ARMED with a new patent that was issued last week covering the process of making genetically engineered tissue plasminogen activator (TPA), Genentech has filed another suit against Wellcome's US drugs company Burroughs Wellcome, its partner Genetics Institute and all of their joint ventures. Genentech is already suing all of them for infringing its patents for purified TPA and for materials used in making recombinant TPA.

The new patent will allow Genentech to protect its US market against TPA manufactured abroad and imported into the United States. The US Congress voted last year to close a loophole in US law that allowed the importing of products made abroad using US patented processes.

Carol Ezzell

\title{
Harvard fights first battle
}

\section{Boston}

HARVARD University, along with the firm US Biochemical Corporation of Cleveland, Ohio, filed a patent infringement suit last week claiming that the Swedishbased company Pharmacia AB has violated the school's exclusive claim to a DNA polymerase-based sequencing technology. It is the first time that Harvard has been involved in such legal action since it began patenting its scientists' work a decade ago.

The patent involves a technique developed at Harvard Medical School by researchers Charles Richardson and Stanley Tabor that uses T7 DNA polymerases to sequence DNA. Exclusive licence to the technology has been granted by Harvard to US Biochemical, which markets its T7 DNA-sequencing products under the trade name of Sequenase. US Biochemical and Harvard are seeking to stop Pharmacia and three US subsidiaries from using the technology in its own DNA-sequencing kits and other related products, and are claiming damages for past infringements which, they say, have gone on "in deliberate defiance" of and "with full knowledge of the facts" of the licensing agreement.

S. Leslie Misrock, senior partner of Pennie \& Edmonds, the law firm representing US Biochemical and Harvard University in the suit, says that the patent involved is currently Harvard's "single most important patent" from a financial standpoint. Although neither Harvard nor US Biochemical will disclose how much the university receives for rights to the technology, it is known that that Harvard earns about $\$ 1.2$ million annually on about 75 biomedical patents. In addition, Misrock claims that Sequenase is a "major" product line for US Biochemical.

Misrock says the decision by Harvard to file suit was made following "very careful consideration" by university personnel and that it was regarded by them as important to "send a message that the university intends to support its licencees". Misrock also stated that US Biochemical and Harvard have identified three potential infringements on the licensing arrangement, but have decided in the Pharmacia suit to focus only on what they perceive to be "the most significant" instance.

Jorgen Winroth, a vice president of the New Jersey-based Pharmacia Inc., a subsidiary of the \$1,200-million Swedish company, stresses that his company's primary product in question, a DNAsequencing kit, is a "very small" part of the company's overall business, making up less than $\$ 500,000$ in worldwide sales.

"Nevertheless, we do respect patent rights, and do not do anything intentionally to infringe upon them", he said, adding that the company is "by no means nonchalant" about the charges.

Winroth hopes that "a happy ending for both parties" can be reached promptly. But the lawyers for US Biochemicals and Harvard say the prospect of a reconciliation "is not even on the table".

Seth Shulman

\section{Rival claims over DNA amplification}

\section{Washington}

DuPoNT is challenging Cetus Corporation's stranglehold on the lucrative market for the DNA amplification technique named the polymerase chain reaction (PCR). Last week, DuPont's attorneys asked a judge to rule that Cetus's PCR patents are invalid, but they will not disclose the basis for their argument.

Cetus received two key patents covering PCR just over two years ago. The PCR technique involves using two specific DNA probes that flank an unknown region of DNA to be studied. Through alternating cycles of heat and cooling, the probes squeeze between the strands of the unknown DNA and initiate an exponential copying process that can yield millions of copies of the unknown DNA sequence (see Nature 331, 461; 1988).

PCR has become widely used, and hundreds of research papers using the technique have been published in the past two years.

PCR has diagnostic as well as research applications: it has been used to screen fetuses for genetic disorders, and several companies are developing tests using PCR to detect genetic material from the AIDS virus. The market for diagnostic PCR kits could reach $\$ 1,500$ million by 1998 .

In a joint venture with Perkin-Elmer, Cetus sells a thermal cycling instrument to automate the PCR process. The cycler comes with two PCR reagent kits and costs $\$ 8,500$.

Permission to use PCR in basic research is included in the cost of the cycler and reagents. But Cetus has licensed all diagnostic uses of PCR to Hoffman LaRoche, and has said it will prosecute those who use PCR without buying one of its machines.

DuPont is also developing 'nucleic acid replication kits' and a thermocycler, and plans to begin selling them later this year.

Now that its products are approaching the market, DuPont's petition says the Cetus patents are "ripe for adjudication". Carol Ezzell 